\title{
Kant's post-1800 disavowal of the highest good argument for the existence of God
}

I have two main goals in this paper. The first is to argue that Kant gave up on his highest good argument for the existence of God around 1800. The second is to revive a dialogue about this thesis that died out in the 1960s: I believe that this dialogue, which seems to have concluded with the naysayers in ascendence, ended prematurely.

The paper is divided into three sections. In the first, I reconstruct Kant's highest good argument in order to introduce the first piece of evidence in favor of my thesis: Kant's deep-seated ambivalence about the various premises in this argument. In the second, I turn to Kant's Opus postumum in order to canvass the second piece of evidence in favor of my thesis: Kant's many claims to the effect that there is only one way to argue for the existence of God, a way which resembles the highest good argument only in taking the moral law as its starting point. In the third, I examine the counterarguments to my thesis as they were introduced in the 1960s, and I explain why I do not find them persuasive: although they undercut some of the evidence mustered by Adickes (the original proponent of my thesis), they leave the evidence on which I build my argument unimpugned. In so doing, I introduce the third and final piece of evidence in favor of my thesis: the continuity between Kant's Opus postumum argument and a line of thought from his earlier work.

\section{Section 1. Kant's highest good argument}

I offer the following enumerated reconstruction of Kant's highest good argument:

1. The highest good is a world in conformity with all moral laws and in which happiness is united to virtue.

2. There is a duty to promote the highest good.

3. Ought implies can.

4. It is possible to promote the highest good only if God exists and we have immortal souls.

5. There are no theoretical proofs for or against God and immortality.

6. In the absence of theoretical proof one way or another [premise 5], the practical grounds from the highest good [premises 1-4] justify belief in God and immortality for the purposes of morality.

7. Therefore, belief in God and immortality is justified for the purposes of morality. 
In this section, I defend this reconstruction and then introduce evidence of Kant's ambivalence about each premise.

Kant's definition of the highest good can be drawn from his Critique of pure reason discussion of the question: what may I hope? He begins by noting that a moral world is one "in conformity with all moral laws" (KrV A808/B836). ${ }^{1}$ But according to Kant, "all hope concerns happiness" (KrV A805/ B833), so the idea of a moral world does not suffice to answer the question of what I may hope; rather, because conforming to moral laws renders one worthy of happiness, Kant maintains that "everyone has cause to hope for happiness in the same measure as he has made himself worthy of it in his conduct" (KrV A809/B837). Thus, the ideal of the highest good is a world in conformity with all moral laws and in which happiness is united to virtue.

Kant is less clear on the second premise of the argument in the Critique of pure reason. But it comes out explicitly in the Critique of practical reason: "[i]t is a duty to realize the highest good to the utmost of our capacity" (KpV AA 5:143n). ${ }^{2}$ Kant does not have an argument for this duty in the way that he does for other duties. ${ }^{3}$ Moreover, it is unclear how such an argument could go given that the moral world exhausts the commands of morality and the highest good is something over and above the moral world. ${ }^{4}$ I shall return to this below. For now, the point is that Kant's use of the premise that agents have a duty to promote the highest good in the Critique of pure reason may be inferred from the third step of the argument: his appeal to "ought implies can" (OIC).

In the Critique of pure reason, Kant appeals to OIC in summarizing his reasoning about the question of hope:

...all hope concerns happiness, and with respect to the practical and the moral law it is the very same as what knowledge and the natural law is with regard to theoretical cognition of things. The former finally comes down to the inference that something is (which determines the ultimate final end) because something ought to happen... (KrV A805fl B833f)

\footnotetext{
${ }^{1}$ Except where otherwise noted, all translations are from the Guyer/Wood Cambridge blue series. All citations follow the standard Academy pagination except for those from the Critique of pure reason (which follow A/B pagination).

2 Similarly, see VNAEF AA 8:419n: "it is a duty to work toward a certain purpose (the highest good)."

${ }^{3}$ Beck contends that "it is seriously misleading to say that there is a command to seek the highest good which is different from the command to fulfil the requirements of duty" $(1963,245)$.

4 This point can be sharpened: it is also unclear how there could be a duty to realize a moral world, for if an agent realizes his/her own moral perfection, s/he has exhausted the commands of morality directed at him/her, and the moral world is something over and above the moral perfection of any single agent.
} 
This is sometimes referred to as the "capacity-expanding" application of OIC. 5 That is, Kant infers from (1) OIC and (2) one ought to promote the highest good to (3) it is possible to promote the highest good, thereby appealing to OIC and modus ponens to expand our capabilities. ${ }^{6}$

Kant's appeal to OIC works together with the fourth premise of my reconstruction to generate practical grounds for belief in the practical postulates. In the Critique of pure reason, for instance, Kant claims that the highest good argument leads to the concept of a will that is "omnipotent,...omniscient,... omnipresent,...eternal..., etc.” (KrV A815/B843). Similarly, in the Critique of practical reason Kant claims that this argument enables him to infer the "omniscience, all-beneficence, omnipotence, and so forth" of the author of the world (KpV AA 5:139). ${ }^{7}$

The fifth premise in my reconstruction might seem unnecessarily strong. On the one side, it might be thought that theoretical proofs could work in concert with practical grounds. On the other side, it might be thought that practical grounds have the potential to trump theoretical proofs to the contrary. Nonetheless, Kant does insist on this idea. ${ }^{8}$ Indeed, in the Critique of practical reason Kant suggests that theoretical proofs for God and immortality would undermine morality because, armed with such proofs, humans, being what they are, would not pursue moral ends from duty but from fear of punishment. ${ }^{9}$ And Kant maintains that theoretical proofs against God and immortality would trump practical ones because practical reason takes primacy over theoretical reason only when its object is theoretically possible. 10

The sixth and final premise in the argument, latent in the passages cited above, is that in the absence of theoretical proof one way or another, the practical grounds from the highest good justify belief in God and immortality. However, it is important not to misunderstand this key step in the argument. Kant is not arguing that morality makes true claims about the world and thereby provides truth-conducive evidence for God and immortality. Rather, Kant's idea is that morality lowers the evidentiary bar required for one to be justified in believing. ${ }^{11}$ Thus, Kant cautions us that although through this argument "reality is

\footnotetext{
5 See Martin $(2009,110)$. Timmermann thinks that Kant uses OIC only in its capacity-expanding (and never in its duty-restricting) form $(2003,118)$. But in On the common saying Kant argues that because humans are unable to renounce their happiness, they have no duty to do so (TP AA 8:276-8).

${ }^{6}$ As reconstructed here, the argument in the Critique of pure reason is enthymematic: the second premise is unexpressed. See $\mathrm{n} 24$ below and the paragraph to which it is appended for a complication regarding the interpretation of this enthymematic premise.

${ }^{7}$ Förster claims that it is first in the Critique of the power of judgment that Kant infers an omniGod from the highest good argument $(2005,130)$. As the paragraph to which this note is appended shows, this is incorrect.

${ }^{8}$ Perhaps most famously when asserting the need to "deny knowledge in order to make room for faith" (KrV Bxxx). But see also, e.g., KpV AA 5:142 and VNAEF AA 8:418n.

${ }^{9} \mathrm{KpV}$ AA 5:146-8.

10 The claim that practical reason presupposes the theoretical possibility of its object is baked into Kant's appeal to OIC (see KpV AA 5:143).

${ }^{11}$ In saying this I am ascribing to Kant a moral encroachment theory of justification like that developed in Pace (2011). For helpful discussion of different kinds of warranted assent in Kant, see Chignell (2007). However, I am wary of the behaviorist connotations of assent in this context.
} 
given to the...ideas of God, freedom, and immortality," nonetheless, this is "always only with reference to the practice of the moral law" (KpV AA 5:138).

Kant takes his highest good argument quite seriously, not only stating it repeatedly in multiple works but also claiming that without the doctrine of the highest good, "we must... regard the moral laws as empty figments of the brain" (KrV A811/B839). However, as noted above and as I shall try to substantiate now, Kant was ambivalent about the premises of this argument. 12

That Kant has different conceptions of the highest good has been explored extensively in the secondary literature. ${ }^{13}$ Indeed, some argue that Kant's different conceptions of happiness (not documented here) are due partly to ambiguity about whether the highest good must be realized in this world or another. ${ }^{14}$ This is related to the fact, noted above, that in the Critique of pure reason the highest good is introduced as something for which to hope, something to give motivational force to the laws of morality; in the Critique of practical reason, by way of contrast, these ideas about motivation are jettisoned (only to be picked up again in later works). ${ }^{15}$ Instead, the highest good is introduced as the "unconditioned totality of the object of pure practical reason" (KpV AA 5:108).16

Issues surrounding the nature of the highest good bleed into issues surrounding the second premise in the above reconstruction, for the conception of the highest good will determine the nature of the duty to promote it. ${ }^{17}$ But there are also other issues regarding the second premise. For example, in the Critique of practical reason, Kant remarks that because "the highest good...is an a priori necessary object of our will and inseparably bound up with the moral law, the impossibility of the first must also prove the falsity of the second" (KpV AA 5:114). ${ }^{18}$ But in the Critique of the power of judgment, Kant suggests that someone who cannot convince herself of the existence of God would not have to surrender the moral law: rather, "[a]ll that would have to be surrendered in that case would be the aim of realizing the final end in

12 Kant's ambivalence extends beyond the substance of the premises: "Kant uses the word 'postulate' rather loosely and...his list of practical postulates varies from place to place...even within the Critique of Practical Reason" (Beck, 1963, 259).

13 See, e.g., (Reath, 1988).

14 Consider: "It is not by chance that there is ambiguity in the definition of happiness and ambiguity surrounding the location of the highest good" (Wike, 1994, 25). I follow Wood (2001, 281n11) in being suspicious of Wike's explanation of Kant's conceptions of happiness.

15 See, for example, RGV AA 6:5, where Kant asserts that the idea of the highest good "meets our natural need, which would otherwise be a hindrance to moral resolve." It might be helpful to consider this in light of the remarks in n4 above and the paragraph to which it is appended. I return to it below.

16 For a fuller discussion of this point (and much else), see Pasternack and Rossi (2014, section 3.5) or Düsing (2002, 105).

${ }^{17}$ Beck points out that if the highest good is conceived as a world in which happiness is proportionate to virtue (as Kant is wont to conceive it) rather than as a world in which everyone is maximally virtuous and maximally happy (as in the above reconstruction), then the Critique of practical reason immortality argument is rendered void: the highest good so conceived would not require holiness or, thus, an infinite temporal progression toward holiness (1963, 268f).

18 Echoing the claim from the Critique of pure reason (reproduced above in the paragraph to which n12 is appended) about morality being an empty figment of the brain without the highest good. 
the world" (KpV AA 5:451). ${ }^{19}$ Both of these passages evince Kant's commitment to OIC. But whereas the first suggests a strong commitment to a duty to promote the highest good (bound up with the legitimacy of morality as a whole), the second suggests a weaker commitment to the pursuit of the highest good, a pursuit that even may be foresworn (without rejecting morality writ large) in case the conditions of its realization are rejected. 20

The preface to the first edition of the Religion within the boundaries of mere reason reveals a yet more complicated picture of Kant's commitment to both the second and third premises. Kant says there that the command to pursue the highest good "does not increase the number of morality's duties" but rather arises from "our natural need" to have an end at which to aim when considering the commands of morality, a need the repudiation of which would be a "hindrance to moral resolve" (RGV AA 6:5). ${ }^{21}$ Kant reiterates this in an extended footnote. ${ }^{22}$ In these passages, to promote the highest good is enjoined by reason, but it exceeds and is not contained in the moral law. ${ }^{23}$ Nonetheless, he goes on to assert that because human capacity does not suffice to bring about the highest good, "an omnipotent moral being must be assumed... under whose care this would come about" (RGV AA 6:8n). This bears on Kant's commitment to OIC (premise 3), for the "ought" in this version of the argument is not the ought of duty but something else. $^{24}$

Kant's ambivalence regarding the fourth premise manifests in his varying explanations of why God and immortality are necessary for the highest good. For instance, in the Critique of practical reason the postulate of immortality flows "from the practically necessary condition of a duration befitting the complete fulfillment of the moral law" (KpV AA 5:132). But in part two of the Religion within the boundaries of mere reason Kant seems to repudiate this, arguing that a change in disposition is sufficient for moral goodness and, therefore, that "notwithstanding his permanent deficiency, a human being can still expect to be generally well-pleasing to God, at whatever point in time his existence be cut

\footnotetext{
19 This point is also made in Pasternack and Rossi (2014, sections 3.5.4-5).

20 This poses a problem for the Düsings' claim that the "essential contents" of the Critique of practical reason highest good argument are preserved in the Critique of the power of judgment $(2002,112)$ : on their account of the former, one cannot relinquish the highest good without giving up all other moral ends, for all other moral ends are subordinate to the highest good (2002, 108).

21 This might be taken to ground an indirect duty to promote the highest good. However, Kant does not say so, and detailed discussion is beyond the scope of this paper.
}

${ }^{22}$ RGV AA 6:7n. Similarly, in an important footnote in On the common saying Kant remarks that "the need for a final end assigned by pure reason... is a need of an unselfish will extending itself beyond observance of the formal law" (TP AA 8:280n). However, he then asserts that "there is...the duty to bring it about as far as we can that such a relation (a world in keeping with the moral highest ends) exists."

${ }^{23}$ Kant's argument for this rests on the assertion that the laws of morality "command absolutely... and thereby...make of duty an object of the highest respect, without proposing to us... an end...such as would constitute some sort of inducement" (RGV AA 6:7n). This might be read as an assertion that there are no ends that are also duties. If so, it is contradicted in the Metaphysics of morals.

${ }^{24}$ Whether Kant was aware of this is unclear; note that in the Critique of pure reason passage reproduced above, Kant appeals to OIC "with respect to the practical and the moral law" (my emphasis). 
short" (RGV AA 6:67).25 Similarly, Förster catalogs no fewer than four separate roles attributed to God in these texts. ${ }^{26}$ And it is also notable that freedom, omitted in my reconstruction above, is sometimes mentioned and sometimes overlooked in Kant's various statements of the highest good argument. All of these shifts suggest Kant's dissatisfaction with his articulation and defense of premise four.

Kant's changing attitude toward the fifth premise is evidenced by his changing attitude toward physicotheology. For example, in the Critique of pure reason Kant argues that "neither in speculative nor in natural theology...do we find even a single significant ground for assuming a single being to set before all natural causes" (KrV A814f/B842f): the highest good argument is what leads (inexorably) to physicotheology (KrV A815f/B843f). But in the Critique of practical reason, Kant claims that even if physicotheology cannot justify belief in an omniGod, "we can well infer from...[the] order, purposiveness, and magnitude [of the world] a wise, beneficent, powerful, and so forth author of it" (KpV AA 5:139). ${ }^{27}$ More, although Kant does not think that physicotheology can justify belief in an omniGod by the time of the Critique of the power of judgment, he does think that it provides the highest good argument with "desired confirmation" (KU AA 5:479). ${ }^{28}$ Note the change in evidential relations: from highest good leading to physicotheology to the two being independent to physicotheology providing confirmation.

With all of this (that is, Kant's repeated and substantive reformulations of the highest good argument) in mind, I submit that it should be unsurprising to find Kant eschewing the highest good argument for the existence of God in the Opus postumum.29

\section{Section 2. Kant's Opus postumum rejection of the highest good argument}

In order to find support for my thesis in the Opus postumum, one must look at the first and seventh convolutes of the text (in volumes 21 and 22 of the Academy edition), which are dated to 1800 or thereafter. ${ }^{30}$

\footnotetext{
${ }^{25}$ Kant's discontent with his immortality argument might be borne out in his claim that belief in immortality "is only a belief in the second rank" (Refl AA 19:644; translation from Wood (1970, 182n)). However, Kant continues unambiguously to support the immortality postulate in published work as late as 1796 (see VNAEF AA 8:418).

${ }^{26}$ See $(2005$, esp. 134f).

27 This poses a problem for the Düsings, who maintain that, according to Kant, theoretical philosophy yields only negative theology $(2002,101)$.

${ }^{28}$ At KU AA 5:445 it provides "incidental confirmation."

${ }^{29}$ It might be objected that these reformulations evince Kant's increasing acuity regarding the highest good. Length constraints prevent me from addressing this objection, which I owe to an anonymous referee, in full. But I think it worth pointing out that Kant goes back and forth repeatedly on these issues (see n15 above and the paragraph to which it is appended) and does not seem always to be aware of either his vacillations or their implications (see n24 above and the paragraph to which it is appended).

${ }^{30}$ See Förster's discussion of Adickes' dating of the manuscript in the translator's introduction to the Cambridge blue series Opus postumum (xxiv-xxix). See also Adickes (1920, part 1).
} 
There are four main ways in which the Opus postumum supports my thesis: (1) Kant articulates (repeatedly) a different argument for the existence of God, one which also falls within the purview of moral theology; (2) Kant claims (repeatedly) that this different argument is the only possible way to justify belief in God; (3) Kant says that the concept of God just is the concept of the author of the laws of duty (a concept that encapsulates the argument referred to in (1)); and (4) the highest good argument has all but disappeared. I shall return to (4) in the next section. For now, I focus on (1), (2) and (3).

In support of (1), consider the following 8 passages:

a) The categor. Imper. and the thereupon grounded knowledge of all man's duties as divine commands is the practical proof of God's being. (OP AA 21:74.8-10) ${ }^{31}$

b) Categorial imperative which our reason expresses through the divine. Freedom under laws, duties as divine commands. There is a God (OP AA 22:104.16-18)

c) There is a God: for there is in moral-practical reason a categorical imperative, which extends to all rational world-beings and through which all world-beings are united. (OP AA 22:105.1-3)

d) Reason proceeds according to the categorical imperative, and the legislator is God.There is a God because there is a categorical imperative. (OP AA 22:106.17-19)

e) Moral-practical reason in the categorical imperative in freedom under laws shows that such a being [as God] exists in the knowledge of all duties as divine commands. (OP AA $22: 108.22-25)^{32}$

f) The sum of all duties as divine commands exterminates atheism, pantheism and the denial of God. (OP AA 22:113.21-23) 33

g) The existence of such a being, however, can only be postulated in a practical respect: Namely, the necessity of acting in such a way as if I stood under such a fearsome-but yet, at the same time, salutary - guidance and also guarantee, in the knowledge of all my duties as divine commands (tanquam non ceu)... (OP AA 22:116.20-24)

h) A command, to which everyone must absolutely give obedience, is to be regarded by everyone as from a being which rules and governs over all. Such a being, as moral, however, is called God. So there is a God. (OP AA 22:127.1-4)

In these passages, Kant articulates a new argument for God's existence. This argument, like the highest good argument, begins from the moral law. However, it does not proceed through the highest good: it appeals directly to the necessity of regarding duties as divine commands, whence it follows that

\footnotetext{
${ }^{31}$ My translation.

32 My translation.

${ }^{33}$ My translation.
} 
God exists (in order to command accordingly). I shall return to this argument toward the end of section 3 below to suggest one way in which it might be fleshed out. For now, I take these 8 passages to establish (1), that in the Opus postumum Kant articulates (repeatedly) a different argument for the existence of God (different from the highest good argument), one which also falls within the purview of moral theology. ${ }^{34}$ Now consider the following 3 passages in support of (2) (which also support (1)):

i) However, there still seems to be the question as to whether this idea, the product of our own reason, has reality or whether it is a mere thought-object (ens rationis), and there remains to us nothing but the moral relationship to this object [namely, God] — which is merely problematic, and which leaves only the formula of the knowledge of all human duties as (tanquam) divine commands, whenever the iron voice of the categorical imperative of duty resounds between all siren temptations of the senses and threatening deterrents. (OP AA 22:117.7-15)

j) Only as hypothetical, however, can such an ens constitute a principle — not as given, but only as thought...but only for the sake of the recognition of our duties as divine commands. (OP AA 22:125.30-126.3)

k) There is only one practically sufficient argument for faith in one God, which is theoretically insufficient — knowledge of all human duties as (tanquam) divine commands. (OP AA 22:127.12-14)

In these passages, Kant says that the only way to justify belief in God is through the moral relationship referred to in passages a-h ("there remains to us nothing but the moral relationship to this object"); that God can be thought as hypothetical "only for the sake of the recognition of our duties as divine commands"; that there is "only one practically sufficient argument" for God, the one occurring in passages a-h, not the highest good argument. To put it bluntly: according to the post-1800 Opus postumum Kant, there exists exactly one argument to justify belief in God, an argument beginning with the idea that agents are compelled to regard their duties as divine commands.

Finally, I reproduce the following 4 passages in support of (3):

1) God is...the personified idea of justice and benevolence... (OP AA 22:108.11-12)

$\mathrm{m})$...he who is justified through the categorical imperative alone to give pronouncements of the same for all rational beings, is God... (OP AA 22:109.7-8) ${ }^{35}$

\footnotetext{
${ }^{34}$ Kant's Reflexionen from this time period are also revealing. Consider the following excerpt from a reflection dated to 1800 : "the concept of God arises from morality. The observance of all moral duties as (instar) divine commands" (Refl AA 19:650.19-20, my translation).

35 My translation.
} 
n) ...a highest being commanding supremely through the categorical imperative, setting all rational beings in the world in the unity of ethical relations - God. (OP AA $22: 113.17-19)^{36}$

o) A being, who is capable of and entitled to command a11 rational beings according to laws of duty (the categorical imperative) of moral-practical reason, is God...(OP AA

22:116.12-14)

In these passages, Kant introduces the concept of God as if derived from the argument in passages a-k: God is justified by virtue of regarding one's duties as divine commands, whence it follows that the concept of God is the concept of a being "who is capable of and entitled to command all rational beings according to laws of duty." Thus, I think passages 1-o provide confirmation for the lesson I am trying to draw from passages a-k.

Many more passages could be cited in support of (1), (2) and (3). ${ }^{37}$ However, I would like to say only two more things before turning to the next section.

First, one might make finer distinctions than I have in setting out the Opus postumum argument for God. ${ }^{38}$ The Opus postumum is a set of notes Kant made for himself, not for publication, and he tries and retries diverse lines of argument, sometimes with subtle (and sometimes with not so subtle) variations. For instance, at OP AA 22:120.1-2 Kant says that "[ $t]$ o prescribe all human duties as divine commands is already contained in every categorical imperative," which suggests that he might take this new argument to be analytic. Another variation is suggested at the end of OP AA 22:121.13-21 when Kant remarks that the knowledge of duties as divine commands engendered through his argument is authorized "as a principle of practical reason, in which there is a valid inference from ought to can." It is unclear what work OIC is doing here, and this is one of the only places in the Opus postumum where OIC is appealed to in this context. One might conjecture that it is a vestige of the highest good argument. However, I shall not pursue such conjectures here: for my purposes, it suffices to point out that the theme on which these variations are made is the disappearance of the highest good.

Second, Kant's new argument for God in the Opus postumum is connected with his Opus postumum argument for the uniqueness of God, one in which he maintains that the existence of more than one

\footnotetext{
36 My translation.

${ }^{37}$ For instance, OP AA $21: 17.2-3,17.12-15,22.28-29,22.30-31,25.10-21,28.11-17,30.4-11,37.11-18,50.20-22,60.31-32$, 79.11-12, 113.9-10, 118.16, 144.24-25, 145.4-5, 146.25-28, 152.18-21 and 157.16-17. See also OP AA 22:49.21-22, 49.23-26, 51.18-52.2, 53.3-6, 54.7-8, 56.1-2, 57.16-18, 57.22-25, 58.3-9, 58.30-32, 59.1-2, 64.21-29, 104.8-12, 105.6-9, 109.20-25, $112.3-10,116.10-11,116.27-117.5,118.11-13,118.14-15,119.20-22,120.8-15,120.24-26,122.3-8,122.22-23,122.24-25$, $126.18-23,127.5-11,127.23-26,128.11-21,128.22-24$ and 129.3-6.

38 Adickes distinguishes four versions (1920, 802-11). Smith collapses Adickes' first two versions but otherwise follows him in this (1962, 638-40). The distinction between the third and fourth versions also might be collapsable given Kant's Opus postumum contention (perhaps articulated under the influence of Lichtenberg (see Smith, 1962, 637f)) that to have an idea of God is to believe in God. (It is on the basis of this contention that some maintain that Kant renounces his critical stance toward the ontological argument in the Opus postumum.)
} 
being who is all-obliging but never obliged is self-contradictory. ${ }^{39}$ Moreover, Kant often seems to want to make both arguments in one fell swoop:

p) The being whose will is a practical law for all rational beings, is the highest moral being...the highest intelligence which is distinguished from all world-beings and which is law-giving by one principle, that is, it is God. There therefore is one God. (OP AA $22: 114.15-19)^{40}$

This connection is more notable because Kant's preoccupation with proving the uniqueness of God in the Opus postumum seems to be connected (sometimes explicitly) with his efforts to prove the uniqueness of the world. ${ }^{41}$ This indicates that Kant's interest in his new argument for God is bound up with a larger research program aimed at a suite of problems he was trying to solve at the time. It thus lends further legitimacy to my thesis.

\section{Section 3. Why I do not find the counterarguments persua- sive}

As noted in the introduction to this paper, my thesis originally was articulated by Adickes in his 1920 commentary on the Opus postumum. ${ }^{42}$ Adickes' commentary, which came out before the Opus postumum was more generally available, makes extensive use of Kant's text and was widely influential. For example, in the second edition of his commentary on the Critique of pure reason, Smith generally follows Adickes' lead in interpreting the Opus postumum, including Adickes' claim regarding Kant's rejection of the highest good argument for the existence of God. ${ }^{43}$ Dakin then follows both Adickes and Smith in an essay on Kant's philosophy of religion. 44

\footnotetext{
39 See, e.g., OP AA 22:124.22-26.

40 My translation. See also OP AA 22:61.8-11. The claim that there is (only) "one principle" might be an attempt to rule out the possibility of two all-but-one-obliging (or three all-but-two-obliging, etc.) but never-obliged beings. But if there can be multiple sources for a single principle, the challenge remains.

${ }^{41}$ I think this comes out especially in the first convolute. See OP AA 21:37.7-8, 40.9-11, 48.24-25, 54.18-20, 55.8, 57.25-26, 71.18-20, 79.10-12, 91.4-5, 140.19-20, 141.1-2, 143.4-6, 143.14, 143.26-27, 144.16-17, 144.22-23, 145.6-8, 151.24-26, 151.27-29, 152.1-2, 152.23-24 and 157.16-18. But compare OP AA 22:49.27-28, 53.7-10, 59.10-12, 64.1, 64.17-18 and 125.1-2 from the seventh convolute.

42 Adickes (1920, part 4, section 2, chapter 4).

${ }^{43}$ Smith (1962 [originally 1923], appendix C).

${ }^{44}$ Dakin (1962 [originally 1939], 413-6).
} 
However, after the Opus postumum became more generally available, Schrader published a criticism of Adickes' argument and the dialogue seems to have died off. In support of this (i.e., that the dialogue died off), I offer three pieces of evidence. First, the Stanford Encyclopedia of Philosophy entry on "Kant's Philosophy of Religion" does not cite Adickes in any of its (extensive) bibliographies, and although it mentions (and repudiates) commentators who think Kant rejected the highest good argument for immortality, it devotes only a short paragraph to consideration of God in Kant's Opus postumum and does not suggest that such consideration might reveal Kant's rejection of the highest good argument for God. ${ }^{45}$ Second, although in his recent monograph on the Opus postumum Förster devotes chapter five to discussion of "The Subject as Person and the Idea of God" and gives (therein) an admirable account of some of the differences in Kant's various highest good arguments for God, Förster does not refer to my thesis or to Adickes anywhere in that chapter or its associated endnotes, and he ends up coming to a different conclusion about Kant on God in the Opus postumum. ${ }^{46}$ Third, prominent commentators writing in the immediate wake of Schrader's criticism (to which I shall advance forthwith) cite this criticism as a decisive rebuttal of Adickes. 47

Schrader begins by pointing out the difficulties inherent in ascertaining Kant's post-1800 views. Schrader argues that "[t]he Opus Postumum is quite similar in character to the Reflexionen" $(1951,230)$. He continues in a footnote: "One can imagine the difficulties that would be involved in trying to ascertain Kant's views if it were necessary to substitute his Reflexionen for the Critique of Pure Reason" (1951, 230n2). Schrader concludes that because there is "no indication" of a shift in Kant's thinking with regard to the highest good argument prior to 1800 , any case for a shift after 1800 "is initially weakened" and must be tenuous, indeed. I would like to say two things about this.

First, there are multiple shifts in Kant's thinking on the highest good argument prior to 1800 . As noted in the first section of this paper, Kant tergiversates on various parts of this argument, and throughout his pre-1800 work he continued to experiment with different versions in ways that often fly in the face of earlier ones. Thus, although there is no clear evidence of Kant's having rejected the highest good argument as a whole prior to 1800 , his texts do contain clear evidence of his dissatisfaction with the argument and, thus, pave the way for his rejection of it.

\footnotetext{
45 Pasternack and Rossi (1994, sections 3.6.3 and 4). The neglect of Adickes is made more noticeable by the inclusion in their second bibliography of Greene's essay on Kant's Religion within the boundaries of mere reason, an essay in which Greene, writing (like Smith) before the full text of the Opus postumum became generally available, accepts Adickes' contention about Kant's abandonment of the highest good argument for God (1960 [originally 1934], lxvf).

46 Förster (2005, chapter 5, esp. 137-47). Given that Förster refers to Adickes elsewhere in the text and even includes Adickes in the index, his silence regarding Adickes in chapter 5 is especially telling. It is also worth pointing out that Förster makes no reference to Adickes or to my thesis in the section on "Practical self-positing and the idea of God" in the translator's introduction to the Cambridge blue series Opus postumum.

47 Consider: "After a careful examination of [the Opus postumum]...Professor G.A. Schrader demonstrated the inadequacy of Adickes' interpretation” (Greene and Silber, 1960, cxl). See also Beck (1963, 274n35). Beck's post-Schrader disavowal of Adickes' thesis is the more remarkable because he previously had subscribed to it (1950 [originally 1949], 47-9).
} 
Second, Schrader's analogy is a bad one. It is true that there are ways in which the Opus postumum is like Kant's Reflexionen and that it would be well nigh impossible to reconstruct the Critique of Pure Reason from the Reflexionen. But on the one side, I am not attempting to reconstruct Kant's post-1800 views writ large: my thesis is about only one specific part of Kant's post-1800 views. And on the other side, I am not attempting to reconstruct Kant's views on this particular question by appeal to a single or even a small number of fragmentary and merely suggestive excerpts. On the contrary, Kant revisits this issue regularly throughout the Opus postumum, and as may be seen from the previous section, his texts are as clear and unequivocal on this score as could be desired.

Schrader next points out that Adickes based his advocacy of my thesis on perceived deficiencies in Kant's highest good argument. For example, Adickes thought that the highest good argument is too objective, and when Kant says in the Opus postumum that faith in God is purely subjective, Adickes takes Kant to have recognized the flaw that he, Adickes, diagnosed. Against this, Schrader complains that Kant characterizes the highest good argument as subjective in his earlier work. 48 Similarly, Adickes thought that the highest good argument introduces a hedonistic principle into Kant's ethics and that Kant came to recognize this in the Opus postumum, whereas Schrader points out that there is no evidence that Kant ever took his highest good argument to introduce hedonism into his moral philosophy and, in fact, there is ample evidence that he did not. 49

I would like to steer a middle course between Adickes and Schrader on these issues. Against Schrader I note that Kant's characterization of the highest good argument as subjective prior to 1800 is no evidence that he did not come to see it as objective later, and the same goes for Adickes' point about hedonism. But against Adickes, I agree with Schrader that there is no evidence that Kant came to view the highest good argument as objectionably objective or hedonistic: there is ample evidence that Kant rejected the highest good argument, but why he did so is a matter of conjecture. Moreover, I do not share Adickes' diagnosis of the argument's deficiencies. I do share Adickes' view that Kant was aware of some of the problems with the highest good argument. ${ }^{50}$ But I take these problems to lie elsewhere than in being too objective or hedonistic.

However, Schrader also points out that the highest good argument has not disappeared from Kant's post-1800 philosophy. For example, consider the following two passages from the first and seventh convolutes, respectively:

Now since wisdom, in a strict sense, only can be attributed to God and such a being at the same time must be endowed with all power; because without this the final end (the high-

\footnotetext{
48 See (1951, 231-3 and 236f). Schrader is followed here by Silber (Greene and Silber, 1960, cxl).

49 See $(1951,234 f)$. Silber argues also that hedonism has a positive place in Kant's philosophy (Greene and Silber, 1960, cxlf).

${ }^{50}$ For evidence I point to places where Kant seems explicitly to disavow earlier versions of the argument (see n20 and n25 above and the paragraphs to which they are appended).
} 
est good) would be an idea without reality; thus the proposition: There is a God becomes an existential proposition. (OP AA 21:149.20-24) $)^{51}$

The first question is: is there a moral, practical reason and together with this a concept of duty as a principle of freedom under laws, finally if there is a Substance which, according to these laws...judges them [men] to be worthy or unworthy of happiness and makes it possible for them to participate in it. (OP AA 22:125.23-27) ${ }^{52}$

In these two passages, Kant makes an argument like the one canvassed in section one of this paper: the existence of God is justified by appeal to the necessity of God for fulfilling the duty to promote the highest good.

In fact, Adickes himself mentions passages in the post-1800 convolutes of the Opus postumum in which Kant rehearses the highest good argument. ${ }^{53}$ Adickes does not take these passages to undermine his thesis because he adopts the sound interpretive principle of considering the convolutes of the Opus postumum holistically: rather than "tear out individual passages and consider them in isolation," Adickes insists that "one must...interpret one passage in terms of others and in terms of the whole background of thought which one is able to infer from their totality" $(1920,772) .{ }^{54}$ Indeed, this is the method that Kant recommends for understanding his work. 55

Schrader is cognizant of Adickes' interpretive method and, in fairness to Schrader, does not take the comparatively few passages from the first and seventh convolutes in which Kant affirms the highest good argument by themselves to invalidate my thesis. ${ }^{56}$ Neither do I. Following in Adickes' footsteps with regard to method, it seems to me that the weight of the (many) passages in which Kant attempts to infer God directly from the Categorical Imperative (taken as a divine command), of the (many) passages in which Kant states that this is the only way to justify belief in God, of the (many) passages in which Kant cashes out the concept of God in terms of divine commands, and of the (many) passages in which Kant appeals to his parallel argument to prove the uniqueness of God - the weight of all of this easily tips the scales against the weight of the passages cited by Schrader (and acknowledged by Adickes).

\footnotetext{
51 My translation.

52 I have used Schrader's translation (1951, 236). However, Schrader cites the passage as being from OP AA 22:126.

53 See $(1920,801 n 2)$. Indeed, I owe the first of the two passages above to Adickes, who labels it C415 (1920, 783). This might come as a surprise to Silber, who attributes to Adickes the assertion that "Kant fails to restate the [highest good] argument in the Opus postumum," an assertion that (says Silber) can be dismissed in the wake of Schrader's investigation (Greene and Silber, 1960, cxlif).

54 This passage is quoted in Schrader $(1951,230)$. I have modified slightly Schrader's translation. Silber also is aware of Adickes' interpretive principle (Greene and Silber, 1960, cxl).

55 See (KrV Bxliv).

56 See $(1951,236)$ : "I would not want to make too much of this passage, and certainly would not attempt to refute Adickes' interpretation solely on the basis of it."
} 
In fact, I think these putatively counter-passages speak in favor of my thesis rather than against it. That is, rather than merely take these passages as counterweight to my thesis which is nonetheless anchored in place by others, I take the presence (and relative scarcity) of these passages to make more impressive the (mass of) passages in which Kant makes his divine command argument, for their presence renders it more difficult to deny that Kant was alive to the difference between these arguments. The presence of these passages shows what Kant could have done but did not do, namely: continue to tinker with the highest good argument, or even just let the highest good argument lie fallow and work on others. Instead of pursuing either of these strategies, however, Kant struggled over and over to articulate a different argument, one which bypasses the highest good, and he claims repeatedly that this is the only viable argument, clearly thereby eschewing the highest good argument. To put the point formulaically, the exception proves the rule.

I shall confront one last criticism from Schrader: he complains that the passages in the Opus postumum in which Kant speaks of the Categorical Imperative as the voice of God "are perfectly consistent with his critical position" (Schrader, 1951, 240). Schrader substantiates this by appeal to excerpts like this one:

...the moral law leads through the concept of the highest good, as the object and final end of pure practical reason, to religion, that is, to the recognition of all duties as divine commands... (KpV AA 5:129) $)^{57}$

In this excerpt (published before the Opus postumum passages considered in the previous section were written), Kant suggests that the Categorical Imperative be regarded as a divine command on the basis of the highest good argument. Schrader takes the continuity between this excerpt and the claims made in the Opus postumum to indicate that Kant has neither repudiated nor modified his earlier position.

I maintain otherwise. Although there is continuity between this excerpt and the Opus postumum argument (in the idea of regarding duties as divine commands), there is a crucial difference: the stepping stone of the highest good all but disappears in the first and seventh convolutes. The reason this is so crucial is that it manifests and, I think, magnifies a difference in the structure of the arguments. That is, the point of conflux between pre-1800 and post-1800 passages (regarding duty as divine command) foregrounds the fact that they diverge in the justificatory structure of the connection between this regarding and belief in God: pre-1800 justifies regarding duty as divine command on belief in God (in turn justified

\footnotetext{
${ }^{57}$ Schrader reproduces this passage on $(1951,239)$, however he cites it as coming from 5:140 $(1951,239$ n5). I have used the Cambridge blue series translation rather than Schrader's except that I have unitalicized the word 'to' in both of its instances.
} 
on the basis of the highest good); post-1800, by way of contrast, justifies belief in God immediately on the inexorable regarding of duty as divine command. ${ }^{58}$

However, there is an even more important continuity (than the one alleged by Schrader) between Kant's pre-1800 work and the Opus postumum existence of God argument. This more important continuity can be found in Kant's Metaphysics of morals and, in particular, in the theory of conscience Kant began to articulate in that work. ${ }^{59}$ For instance, consider the following two passages:

Such an ideal person (the authorized judge of conscience) must be a scrutinizer of hearts, since the court is set up within the human being. But he must also... [be] a person in relation to whom all duties whatsoever are to be regarded as...his commands... Now since such a moral being must also have all power...in order to give effect to his laws... and since such an omnipotent moral being is called God, conscience must be thought of as the subjective principle of being accountable to God for all one's deeds. (MS AA 6:439)60

The formal aspect of all religion, if religion is defined as "the sum of all duties as (instar) divine commands," belongs to philosophic morals, since this definition expresses only the relation of reason to the idea of God which reason makes for itself... we cannot very well make obligation (moral constraint) intuitive for ourselves without thereby thinking of another's will, namely God's (of which reason in giving universal laws is only the spokesman). (MS AA 6:487)61

In the first of these two passages, Kant argues that (1) the authorized judge of conscience is (a) a moral being (qua imposer of obligation) and (b) omnipotent (qua judge able to give effect to the laws of obligation); (2) a moral omnipotent being is called God; and therefore (3) conscience should be thought of as an agent's being accountable to God. Similarly, in the second passage Kant argues that the only way in which

\footnotetext{
58 It is important to Adickes that Kant's post-1800 God argument came from Kant himself, that Kant was not, say, merely writing under the influence of Lichtenberg (1920, section 344). I take the fact that Kant clearly had thought about regarding duty as divine command before 1800 to lend support to this. In fact there is a plethora of pre-1800 texts showing that this idea is not new to the post-1800 Kant, although it is not generally deployed in these texts to justify belief in God. For example, see KU AA 5:481; RGV AA 6:84, 99, 110, 153f, 192; MS AA 6:227, 440, 443, 487; SF AA 7:36; VNAEF AA 8:418; VAMS AA 23:401.14-15; and Br AA 10:192.24-32. I owe the reference to 6:227 to Beck (1963, 280n55), who also cites Br AA 11:137.7-12.

${ }^{59}$ As far as I know, this continuity was first noted by Reinhard (1927, section I.2).

60 Reinhard refers to this passage on $(1927,24)$.

${ }^{61}$ Reinhard refers to this passage on $(1972,18)$, interpreting it as an alternate solution to the problem with which Kant is grappling at MS AA 6:417, that "The concept of a duty to oneself contains (at first glance) a contradiction." However, in the passage to which this footnote is appended, Kant is talking about all duties, not only duties to oneself.
} 
obligation can be made intuitive is by thinking of it as having been generated by another's will and, in particular, by the will of God. ${ }^{62}$

For current purposes, what is most important about these two passages is that both justify belief in God on the basis of regarding one's duties as divine commands without appeal to the highest good. This gives more grist to grind against Schrader's first point considered above about there being "no indication" of a shift in Kant's thinking with regard to the highest good argument prior to $1800 .{ }^{63}$ As already remarked, there is abundant evidence of Kant's pre-1800 dissatisfaction with the various parts of the highest good argument. Moreover, as can be seen from these two passages, there is also evidence of Kant's pre-1800 attempts to spell out new grounds for belief in God, grounds which are (prima facie) independent of the highest good and which are based on the very idea that seems so to captivate Kant in the first and seventh convolutes of the Opus postumum: believing in God on the basis of regarding one's duties as divine commands (rather than the other way around). ${ }^{64}$

These passages from the Metaphysics of morals also can be used to give more structure to the Opus postumum argument explored in the previous section. Perhaps Kant's idea is that the voice of conscience, the "iron voice" of the Categorical Imperative (see passage i above), should be regarded as the voice of God because its pronouncements are those of a moral being and because the being is a judge, one with omniscience (or at least knowledge of the heart) and various other attributes that render it most appropriate to regard it as divine. However, this must be admitted to be conjectural extrapolation. ${ }^{65}$

\section{Conclusion}

In section 1 of this paper, I reconstructed Kant's highest good argument and gave evidence of Kant's dissatisfaction with the various premisses of this argument; in section 2, I gave evidence to support my thesis that Kant gave up on this argument around 1800; and in section 3, I explained why I do not find the existing counterarguments to my thesis persuasive, introducing along the way evidence of continuity between Kant's pre-1800 and post-1800 non-highest-good remarks on the existence of God. Perhaps my arguments and my responses to the existing counterarguments will not stand the test of time. Perhaps better counterarguments will appear. But as noted in the introduction to this paper, my goal is not only to argue for my

\footnotetext{
62 Despite the similarity between these passages, it should be noted that in the second there is no mention of omnipotence or of scrutinizing the heart.

${ }^{63}$ It also lends further support to Adickes' thesis that Kant's post-1800 God argument came from Kant himself (see n58 above).

${ }^{64}$ Reinhard finds evidence of this line of thought also in Kant's Lectures on ethics $(1927,16 f)$.

65 Webb, writing before Schrader and following Adickes, finds a strong continuity between the Opus postumum argument and other pre-1800 lines of thought: "I...do not find any really new doctrine in the Opus postumum" (1926, 196). I am more cautious: I am unsure whether the Opus postumum argument is new. The point I am most concerned about is not whether a genuinely novel and unprecedented line of argument appears beginning around 1800 but rather whether a genuinely old and thoroughly explored line of argument is given up around 1800.
} 
thesis: it is also to revive a dialogue initiated by Adickes in 1920. And even if my thesis is ultimately overthrown, this second goal, which is probably the worthier one, thereby will have been accomplished. ${ }^{66}$

66 I would like to express my deepest gratitude and indebtedness to Allen Wood, who generously provided me with feedback on an earlier (and significantly worse) version of this paper. 


\section{Bibliography}

Erich Adickes (1920): Kants Opus postumum, Reuther \& Reichard.

Lewis White Beck (1950): Introduction, in: Kant: Critique of practical reason and other writings in moral philosophy (trans. and ed. Beck), The University of Chicago Press.

Lewis White Beck (1963): A commentary on Kant's critique of practical reason, The University of Chicago Press.

Andrew Chignell (2007): Belief in Kant, in: The Philosophical Review, 116.3, pp. 323-360.

A. Hazard Dakin (1962): Kant and religion, in: G. Whitney and D. Bowers (ed.): The Heritage of Kant, Russel \& Russell, pp. 405-420.

Edith and Klaus Düsing (2002): Negative und positive Theologie bei Kant, in: D. Hüning, G. Stiening, U. Vogel (ed.): Festschrift für B. Tuschling zum 65. Geburtstag, Berlin, pp. 85-118.

Eckart Förster (2000): Kant’s Final Synthesis, Harvard University Press.

Theodore Greene (1960): The historical context and religious significance of Kant's Religion, in: Kant: Religion within the limits of Reason alone (trans. T. Greene and H. Hudson), First Harper Torchbook, pp. ix-lxxviii.

Thomas Greene and John Silber (1960): Preface to the second edition of this translation, in: Kant: Religion within the limits of Reason alone (trans. T. Greene and H. Hudson), First Harper Torchbook, pp. cxxxix-cxlii.

Wayne Martin (2009): Ought but cannot, in: Proceedings of the Aristotelian Society New Series 109, pp. 103-128.

Michael Pace (2011): The Epistemic Value of Moral Considerations, in: Noûs 45.2, pp. 239-268.

Lawrence Pasternack and Philip Rossi (2014): Kant's Philosophy of Religion, in: E. Zalta (ed.): The Stanford Encyclopedia of Philosophy, URL $=<$ https://plato.stanford.edu/archives/fall2014/entries/kant-religion/>. 
Andrews Reath (1988): Two conceptions of the highest good in Kant, in: Journal of the history of philosophy 26.4, pp. 593-619.

Walter Reinhard (1927): Ueber das Verhältnis von Sinnlichkeit und Religion bei Kant, Paul Haupt Akademische Buchhandlung vorm. Max Drechsel.

George Schrader (1951): Kant's Presumed Repudiation of the "Moral Argument" in the "Opus Postumum," in: Philosophy 26.98, pp. 228-241.

Norman Kemp Smith (1962): A Commentary to Kant's ‘Critique of Pure Reason', Humanities Press.

Jens Timmermann (2003): Sollen und können, in: Philosophiegeschichte und logische Analyse 6, pp. 113122.

Clement Webb (1926): Kant's philosophy of religion, Oxford University Press.

Victoria Wike (1994): Kant on happiness in ethics, State University of New York Press.

Allen Wood (1970): Kant's moral religion, Cornell University Press.

Allen Wood (2001): Kant versus Eudaemonism, in: P. Cicovacki (ed.): Kant's Legacy, University of Rochester Press, pp. 261-82. 